\title{
3 Research Soure \\ The Role of miRNA-424 in Various Cancers: Focusing on Drug Resistance and Sensitivity
}

\section{Fatemeh Najafi}

Tabriz University of Medical Sciences

\section{Shohreh Karimi}

Tabriz University of Medical Sciences

\section{Bahareh Kazemi}

Tabriz University of Medical Sciences

\section{Zahra Foruzandeh}

Tabriz University of Medical Sciences

\section{Sajjad Vakili}

Tabriz University of Medical Sciences

\section{Farhad Seif}

Tehran University of Medical Sciences School of Medicine

Mahdi Derakhshani

Tabriz University of Medical Sciences

\section{Saeed Solali}

Tabriz University of Medical Sciences

MohammadReza Alivand ( $\square$ mohammadreza_alivand@yahoo.com )

Tabriz University of Medical Sciences

\section{Research Article}

Keywords: MicroRNAs, miR-424, Cancer, Posttranscriptional, Proliferation, Differentiation, Apoptosis, Invasion, Angiogenesis, Drug resistance

Posted Date: November 29th, 2021

DOI: https://doi.org/10.21203/rs.3.rs-1108254/v1

License: (c) (i) This work is licensed under a Creative Commons Attribution 4.0 International License. Read Full License 


\section{Abstract}

However, advanced technologies have been developed in the treatment of various cancers the mortality rate of this disease is still very high. Drug resistance is a major problem for cancer patients which causes the treatment process to fail. In addition to inhibiting drug resistance, targeted therapy is also very important in its treatment. Nowadays, miRNAs have gained increasing interest in recent years which play a major role in both drug resistance and target therapy. MicroRNA (miRNA) is an important part of non-coding RNA that regulates gene expression at a posttranscriptional level. One of these microRNAs is miR-424 that by targeting genes involved in various cellular processes can participate in proliferation, differentiation, apoptosis, invasion, angiogenesis, and drug resistance and sensitivity. In this study, we collected the role of miR-424 in a variety of cancers and by identifying the role of miR-424 in drug resistance we can reduce the effect of drug resistance in many cancers.

\section{Introduction}

Cancer is the second leading cause of death in the world. There were an estimated 18 million cancer cases around the world in 2018, of these 9.5 million cases were in men and 8.5 million in women [1]. The highest prevalence of cancers is related to lung cancers $(12.5 \%)$, breast cancers $(12.3 \%)$, colorectal cancers $(10.6 \%)$, and prostate cancers $(7.5 \%)$. About $50 \%$ of cancers can be treated before the onset of clinical symptoms due to rapid diagnosis. There have been many successes in the diagnosis and treatment of cancer in recent years [1]. Damage to healthy cells during chemotherapy and resistance to chemotherapy drugs are major problems in the treatment of this disease. So targeted therapy and reduction of drug resistance are the most important reasons for successful cancer treatment. [2]. One of the factors involved in both targeted therapy and reduction of drug resistance is microRNA. MicroRNAs are small, single-stranded, untranslatable RNAs and have between 18-24 nucleotides whose function is to bind the 3 ' UTR region of their target gene and regulate its expression by impairing the translation. miRNAs are important regulators in diverse biological processes of cancer, such as cell proliferation, apoptosis, angiogenesis, cell differentiation, adhesion and metastasis [3, 4].

\subsection{Properties and functions of miR-424}

miR-424 is a member of the family of miR15/107. Members of this family have AGCAGC sequences in the Seed area and are involved in the cell division, apoptosis, stress responses, and cancer. miR-424 or its autologous miR-322 and miR-503 are encoded as a cluster by H19X on the Xq2603 chromosome. miR-424 is involved in cell cycle regulation, EMT, differentiation, hypoxia, proliferation, apoptosis, invasion, angiogenesis, and drug resistance and sensitivity. Transcription factor PU1 is one of the inducers of miR-424 [5]. In this study, we looked at the role of miR-424 in a variety of cancers and described the target genes of miR-424 and we have specifically focused on its role in drug resistance and sensitivity.

\section{Mirna Biogenesis}

The construction of miRNAs begins with the transcription of RNA polymerase Il. The resulting miRNA is the primary miRNA (pri-miRNA). Then there is Drosha enzyme which is a type III RNase. It is connected to the primiRNA with the help of cofactor protein DGCR8. The two RNase sites present in Drosha mediate the cleavage of $3 /$ and $5 /$ strand of pri-miRNA to generate pre-miRNA. Then, exportin 5 causes pre-miRNA to exit the nucleus into the cytosol. In the cytosol, the Dicer and TAR RNA binding protein (TRBP) bind to the pre-miRNA and cut the 
terminal loop and resulting in a miRNA duplex. In the next step, miRNA Duplex enters the RNA-induced silencing complex (RISC). Finally, the miRNA Duplex processor is performed in the RISK complex by argonaute (AGO) family of proteins and a mature miRNA is obtained [5].

\section{Drug Resistance Or Sensitivity And Micrornas}

Drug resistance is a major problem in patients with advanced cancer. It is the cause of $90 \%$ of deaths in patients who are resistant to chemotherapy drugs. MicroRNAs can play a role in drug resistance or sensitivity by targeting genes that are effective in responding to chemotherapy drugs. Another way that microRNAs can affect drug resistance and sensitivity is survival and apoptosis signaling pathways and drug transport routes [6]. The function of miR-424 in tumor inhibition or tumor induction as well as in drug resistance and sensitivity in a variety of cancers is listed.

\section{Target Genes Of Mir-424 And Its Role In Drug Resistance And Sensitivity In Various Cancers}

According to multiple studies and investigations, miR-424 plays a vital role in various cancers. (Fig. 1 The role of miR-424 through inhibition or induction of various genes in inhibition of proliferation, cell cycle, EMT and induction of apoptosis and differentiation), (Table 1) 
Table 1

Expression of miR-424 and its target genes and its effect on malignancies

\begin{tabular}{|c|c|c|c|c|c|c|}
\hline $\begin{array}{l}\text { MiR- } \\
424\end{array}$ & Related cancer & $\begin{array}{l}\text { Expression of } \\
\text { miR }\end{array}$ & Target gene & mechanism & $\begin{array}{l}\text { Type } \\
\text { of } \\
\text { study }\end{array}$ & References \\
\hline \multirow[t]{5}{*}{$\begin{array}{l}\operatorname{miR}- \\
424\end{array}$} & $\begin{array}{l}\text { Endometrial } \\
\text { Carcinoma }\end{array}$ & $\begin{array}{l}\text { Decrease in } \\
\text { tissues with } \\
\text { high } \\
\text { differentiation }\end{array}$ & E2F6 & $\begin{array}{l}\text { Inhibit EMT by } \\
\text { overexpression of E- } \\
\text { cadherin }\end{array}$ & $\begin{array}{l}\text { In } \\
\text { vitro }\end{array}$ & [14] \\
\hline & $\begin{array}{l}\text { Endometrial } \\
\text { Carcinoma }\end{array}$ & - & E2F7 & $\begin{array}{l}\text { Arrest S phase of } \\
\text { cell cycle and inhibit } \\
\text { proliferation }\end{array}$ & $\begin{array}{l}\text { In } \\
\text { vitro }\end{array}$ & [49] \\
\hline & $\begin{array}{l}\text { Endometrial } \\
\text { Carcinoma }\end{array}$ & - & MMSET & $\begin{array}{l}\text { Targeting of } \\
\text { MMSET inhibit } \\
\text { Twist } 1 \text { and inhibit } \\
\text { EMT }\end{array}$ & $\begin{array}{l}\text { In } \\
\text { vitro }\end{array}$ & {$[50]$} \\
\hline & $\begin{array}{l}\text { Cutaneous } \\
\text { Melanoma }\end{array}$ & Decease & $\begin{array}{l}\text { PDGRa } \\
\text { CXCL10/IP- } \\
10\end{array}$ & $\begin{array}{l}\text { Promote mucosal } \\
\text { defense and inhibit } \\
\text { proliferation }\end{array}$ & $\begin{array}{l}\text { In } \\
\text { vitro }\end{array}$ & [51] \\
\hline & $\begin{array}{l}\text { Esophageal } \\
\text { Squamous Cell } \\
\text { Carcinoma }\end{array}$ & $\begin{array}{l}\text { Increase due } \\
\text { to connection } \\
\text { of E2F1 to } \\
\text { miR-424 }\end{array}$ & PRKCD & $\begin{array}{l}\text { Inhibit proliferation } \\
\text { by reducing of P21 } \\
\text { and inhibit } \\
\text { transition G1/S }\end{array}$ & $\begin{array}{l}\text { In } \\
\text { vitro }\end{array}$ & [22] \\
\hline \multirow[t]{5}{*}{$\begin{array}{l}\text { miR- } \\
424\end{array}$} & $\begin{array}{l}\text { Esophageal } \\
\text { Squamous Cell } \\
\text { Carcinoma }\end{array}$ & - & WEE1 & $\begin{array}{l}\text { Inhibit CDC2 and } \\
\text { transition } \mathrm{G} 2 / \mathrm{M}\end{array}$ & $\begin{array}{l}\text { In } \\
\text { vitro }\end{array}$ & [22] \\
\hline & Gastric Cancer & increase & LATS1 & $\begin{array}{l}\text { Promote GC growth } \\
\text { and invasion }\end{array}$ & $\begin{array}{l}\text { In } \\
\text { vivo }\end{array}$ & {$[5]$} \\
\hline & Gastric Cancer & - & $\operatorname{circLARP}_{4}$ & $\begin{array}{l}\text { Increasing LARP4 } \\
\text { reduce miR-424 and } \\
\text { have tumor } \\
\text { suppression by } \\
\text { regulation } \\
\text { miR424/LATS1/YAP } \\
\text { signaling }\end{array}$ & $\begin{array}{l}\text { In } \\
\text { vivo }\end{array}$ & {$[5]$} \\
\hline & Gastric Cancer & - & NNT-AS1 & $\begin{array}{l}\text { Inhibition of NNT- } \\
\text { AS1 inhibit cell cycle } \\
\text { in G0/G1 phase due } \\
\text { to decreasing CDK6. } \\
\text { CyclinE1.D } 1\end{array}$ & $\begin{array}{l}\text { In } \\
\text { vivo }\end{array}$ & [52] \\
\hline & Gastric Cancer & - & SMURF1 & $\begin{array}{l}\text { Increasing of } \\
\text { SMURF1 due to } \\
\text { reduction of miR- } \\
424 \text { result in drug } \\
\text { resistant }\end{array}$ & $\begin{array}{l}\text { In } \\
\text { vivo }\end{array}$ & [21] \\
\hline $\begin{array}{l}\text { miR- } \\
424\end{array}$ & $\begin{array}{l}\text { Hepatocellular } \\
\text { Carcinoma }\end{array}$ & Decrease & AKT3/E2F3 & $\begin{array}{l}\text { Targeting } \\
\text { AKT3/E2F3 repress } \\
\text { cell cycle/E2f } \\
\text { signaling }\end{array}$ & $\begin{array}{l}\text { In } \\
\text { vivo }\end{array}$ & [31] \\
\hline
\end{tabular}




\begin{tabular}{|c|c|c|c|c|c|c|}
\hline $\begin{array}{l}\text { MiR- } \\
424\end{array}$ & Related cancer & $\begin{array}{l}\text { Expression of } \\
\text { miR }\end{array}$ & Target gene & mechanism & $\begin{array}{l}\text { Type } \\
\text { of } \\
\text { study }\end{array}$ & References \\
\hline & $\begin{array}{l}\text { Non-Small Cell } \\
\text { Lung Cancer }\end{array}$ & Decrease & LYPLA1 & $\begin{array}{l}\text { LYPLA1 interact } \\
\text { with CD95 so } \\
\text { inhibition of that } \\
\text { can induce } \\
\text { apoptosis }\end{array}$ & $\begin{array}{l}\text { In } \\
\text { vitro }\end{array}$ & [25] \\
\hline & $\begin{array}{l}\text { Head and Neck } \\
\text { Squamous Cell } \\
\text { Carcinoma }\end{array}$ & - & TNFAIP1 & $\begin{array}{l}\text { TNFAIP1 is a tumor } \\
\text { inhibitor so } \\
\text { inhibition of that } \\
\text { increase migration } \\
\text { and invasion }\end{array}$ & $\begin{array}{l}\text { In } \\
\text { vitro }\end{array}$ & [29] \\
\hline & Glioma & Decrease & PVT1 & $\begin{array}{l}\text { PVT1 connect to } \\
\text { miR424 and } \\
\text { suppress that can } \\
\text { control cell growth }\end{array}$ & $\begin{array}{l}\text { In } \\
\text { vitro } \\
\text { In } \\
\text { vivo }\end{array}$ & [34] \\
\hline & $\begin{array}{l}\text { Colorectal } \\
\text { Cancer }\end{array}$ & Decrease & $\begin{array}{l}\text { AKT3 } \\
\text { PSAT1 }\end{array}$ & $\begin{array}{l}\text { Reduce proliferation } \\
\text { and induce } \\
\text { apoptosis }\end{array}$ & $\begin{array}{l}\text { In } \\
\text { vivo }\end{array}$ & [53] \\
\hline & Osteosarcoma & Decrease & FASN & $\begin{array}{l}\text { Decrease activity of } \\
\text { this enzyme limits } \\
\text { migration and } \\
\text { invasion }\end{array}$ & $\begin{array}{l}\text { In } \\
\text { vitro }\end{array}$ & [23] \\
\hline $\mathrm{miR}-$ & Osteosarcoma & - & Cyclin A2 & Inhibits cell cycle & In & [24] \\
\hline & & & CCNA2 & & & \\
\hline & $\begin{array}{l}\text { Ovarian } \\
\text { carcinoma }\end{array}$ & Increase & - & $\begin{array}{l}\text { Increasing of miR- } \\
424 \text { in LDH+ cell line } \\
\text { is associated with } \\
\text { chemoresistant }\end{array}$ & $\begin{array}{l}\text { In } \\
\text { vitro } \\
\text { In } \\
\text { vivo }\end{array}$ & [39] \\
\hline & $\begin{array}{l}\text { Epithelial } \\
\text { Ovarian Cancer }\end{array}$ & Decrease & CCAT2 & $\begin{array}{l}\text { CCAT2 is oncogene } \\
\text { with poor prognosis }\end{array}$ & $\begin{array}{l}\text { In } \\
\text { vitro }\end{array}$ & [54] \\
\hline & $\begin{array}{l}\text { Ovarian Clear } \\
\text { Cell Carcinoma }\end{array}$ & Decrease & DCLK1 & $\begin{array}{l}\text { Knockdown of } \\
\text { DCLK1 inhibits } \\
\text { tumor growth }\end{array}$ & $\begin{array}{l}\text { In } \\
\text { vitro }\end{array}$ & [55] \\
\hline & $\begin{array}{l}\text { Pancreatic } \\
\text { cancer }\end{array}$ & Increase & sosc6 & $\begin{array}{l}\text { Induce growth, } \\
\text { invasion, migration } \\
\text { with inhibiting } \\
\text { SOSC6 }\end{array}$ & $\begin{array}{l}\text { In } \\
\text { vitro }\end{array}$ & [56] \\
\hline & $\begin{array}{l}\text { Papillary thyroid } \\
\text { carcinoma }\end{array}$ & Increase & $\mathrm{BCL} 2$ & $\begin{array}{l}\text { Targeting BCL2 are } \\
\text { associated with } \\
\text { high-risk }\end{array}$ & $\begin{array}{l}\text { In } \\
\text { vitro }\end{array}$ & [57] \\
\hline & Prostate cancer & Increase & COPI & $\begin{array}{l}\text { Targeting COPI } \\
\text { increase STAT3 and } \\
\text { STAT3 have } \\
\text { important role in } \\
\text { tumor progression }\end{array}$ & $\begin{array}{l}\text { In } \\
\text { vitro }\end{array}$ & [58] \\
\hline
\end{tabular}




\begin{tabular}{|c|c|c|c|c|c|c|}
\hline $\begin{array}{l}\text { MiR- } \\
424\end{array}$ & Related cancer & $\begin{array}{l}\text { Expression of } \\
\text { miR }\end{array}$ & Target gene & mechanism & $\begin{array}{l}\text { Type } \\
\text { of } \\
\text { study }\end{array}$ & References \\
\hline \multirow{15}{*}{$\begin{array}{l}\text { miR- } \\
424\end{array}$} & \multirow[t]{2}{*}{ Prostate cancer } & \multirow[t]{2}{*}{-} & PD1-PDL1 & \multirow{2}{*}{$\begin{array}{l}\text { Increase immune } \\
\text { response }\end{array}$} & \multirow{2}{*}{$\begin{array}{l}\text { In } \\
\text { vivo }\end{array}$} & \multirow[t]{2}{*}{ [59] } \\
\hline & & & $\begin{array}{l}\text { CTALA4- } \\
\text { B7.1/2 }\end{array}$ & & & \\
\hline & $\begin{array}{l}\text { Tongue } \\
\text { Squamous Cell } \\
\text { Carcinoma }\end{array}$ & Increase & TGFß3 & Promote EMT & $\begin{array}{l}\text { In } \\
\text { vivo }\end{array}$ & [60] \\
\hline & Renal Cancer & Decrease & WEE1 & $\begin{array}{l}\text { Targeting WEE1 } \\
\text { inhibit transition of } \\
\text { G2/M }\end{array}$ & $\begin{array}{l}\text { In } \\
\text { vitro }\end{array}$ & [61] \\
\hline & Bladder cancer & $\begin{array}{l}\text { Increase in } \\
\text { cells that } \\
\text { DNMT1 } \\
\text { inactivated }\end{array}$ & EGFR & Inhibit EMT & $\begin{array}{l}\text { In } \\
\text { vitro }\end{array}$ & [37] \\
\hline & \multirow[t]{3}{*}{ Breast Cancer } & \multirow[t]{3}{*}{ Increase } & CDK1 & \multirow[t]{3}{*}{ Control cell cycle } & \multirow{3}{*}{$\begin{array}{l}\text { In } \\
\text { vitro }\end{array}$} & \multirow[t]{3}{*}{ [11] } \\
\hline & & & YAP & & & \\
\hline & & & ERK1/2 & & & \\
\hline & \multirow[t]{4}{*}{ Breast Cancer } & \multirow[t]{4}{*}{-} & CCND2 & \multirow[t]{4}{*}{ Inhibit proliferation } & \multirow{4}{*}{$\begin{array}{l}\text { In } \\
\text { vitro }\end{array}$} & \multirow[t]{4}{*}{ [12] } \\
\hline & & & CDK6 & & & \\
\hline & & & CDC25A & & & \\
\hline & & & CHK1 & & & \\
\hline & \multirow[t]{2}{*}{ Breast Cancer } & \multirow[t]{2}{*}{-} & SMAD7 & SMAD7 & \multirow{2}{*}{$\begin{array}{l}\text { In } \\
\text { vitro }\end{array}$} & \multirow[t]{2}{*}{ [14] } \\
\hline & & & SMURF2 & $\begin{array}{l}\text { SMURF2 are } \\
\text { regulator of TGFß } \\
\text { pathway }\end{array}$ & & \\
\hline & Cervical cancer & Decrease & CUL2 & $\begin{array}{l}\text { CUL2 is E3 ubiquitin } \\
\text { ligase induce } \\
\text { proliferation by } \\
\text { transition } \mathrm{G} 1 / \mathrm{S}\end{array}$ & $\begin{array}{l}\text { In } \\
\text { vitro }\end{array}$ & [62] \\
\hline \multirow[t]{3}{*}{ miR424 } & Cervical cancer & - & PVT1 & $\begin{array}{l}\text { Inhibiting of PVT1 } \\
\text { inhibit proliferation }\end{array}$ & $\begin{array}{l}\text { In } \\
\text { vitro }\end{array}$ & [63] \\
\hline & Cervical cancer & - & RBBP6 & $\begin{array}{l}\text { Targeting RBBP6 } \\
\text { result in not binding } \\
\text { of P53/RB1 so } \\
\text { inhibit proliferation }\end{array}$ & $\begin{array}{l}\text { In } \\
\text { vitro }\end{array}$ & [64] \\
\hline & $\begin{array}{l}\text { Cervical } \\
\text { intraepithelial } \\
\text { neoplasia }\end{array}$ & Increase & APTX & $\begin{array}{l}\text { Targeting APTX } \\
\text { increase sensitivity } \\
\text { of radiotherapy } \\
\text { resistant cell line }\end{array}$ & $\begin{array}{l}\text { In } \\
\text { vitro }\end{array}$ & [65] \\
\hline
\end{tabular}




\begin{tabular}{|c|c|c|c|c|c|c|}
\hline $\begin{array}{l}\text { MiR- } \\
424\end{array}$ & Related cancer & $\begin{array}{l}\text { Expression of } \\
\text { miR }\end{array}$ & Target gene & mechanism & $\begin{array}{l}\text { Type } \\
\text { of } \\
\text { study }\end{array}$ & References \\
\hline & Hemangioma & Decrease & VEGFR2 & $\begin{array}{l}\text { Inhibit } \\
\text { phosphorylation of } \\
\text { AKT, ERK so inhibit } \\
\text { cell growth }\end{array}$ & $\begin{array}{l}\text { In } \\
\text { vivo }\end{array}$ & [66] \\
\hline & Senile & Decrease & MEK1 & Limit cell growth & $\ln$ & [67] \\
\hline & & & Cyclin E1 & & & \\
\hline & $\begin{array}{l}\text { Infantile } \\
\text { Hemangioma }\end{array}$ & Decrease & MALAT1 & $\begin{array}{l}\text { Restrain C-MYC, } \\
\text { cyclin D1,BCL2 and } \\
\text { increase apoptosis }\end{array}$ & $\begin{array}{l}\text { In } \\
\text { vivo }\end{array}$ & [68] \\
\hline & $\begin{array}{l}\text { Infantile } \\
\text { Hemangioma }\end{array}$ & - & FGF/FGFR1 & $\begin{array}{l}\text { Inhibit } \\
\text { phosphorylation of } \\
\text { ERK } 1 / 2 \text { and stop } \\
\text { migration and } \\
\text { invasion }\end{array}$ & $\begin{array}{l}\text { In } \\
\text { vivo }\end{array}$ & [69] \\
\hline & $\begin{array}{l}\text { Acute myeloid } \\
\text { leukemia }\end{array}$ & Decrease & PLAG1 & $\begin{array}{l}\text { Sensitize cell into } \\
\text { TRAlL-induce } \\
\text { apoptosis }\end{array}$ & $\begin{array}{l}\text { In } \\
\text { vitro }\end{array}$ & [45] \\
\hline & $\begin{array}{l}\text { Acute myeloid } \\
\text { leukemia }\end{array}$ & - & miR-9 & $\begin{array}{l}\text { Induce } \\
\text { differentiation in } \\
\text { THP1 cell lines }\end{array}$ & $\begin{array}{l}\text { In } \\
\text { vitro }\end{array}$ & [46] \\
\hline & $\begin{array}{l}\text { Chronic myeloid } \\
\text { leukemia }\end{array}$ & Decrease & $\mathrm{ABL} / \mathrm{BCR}$ & $\begin{array}{l}\text { Induce apoptosis } \\
\text { and inhibit } \\
\text { proliferation and } \\
\text { sensitize cells to } \\
\text { imatinib }\end{array}$ & $\begin{array}{l}\text { In } \\
\text { vitro }\end{array}$ & [47] \\
\hline & $\begin{array}{l}\text { Chronic } \\
\text { lymphocytic } \\
\text { leukemia }\end{array}$ & Decrease & PLAG1 & $\begin{array}{l}\text { PLAG1 has } \\
\text { important role in } \\
\text { pathogenesis of } \\
\text { CLL }\end{array}$ & $\begin{array}{l}\text { In } \\
\text { vivo }\end{array}$ & [70] \\
\hline & $\begin{array}{l}\text { Diffuse large B- } \\
\text { cell }\end{array}$ & Increase & SIAH1 & $\begin{array}{l}\text { SIAH1 is a E3- } \\
\text { ubiquitous ligase }\end{array}$ & $\begin{array}{l}\text { In } \\
\text { vivo }\end{array}$ & [71] \\
\hline & lymphoma & & & $\begin{array}{l}\text { stream of P53 and it } \\
\text { has anti-tumor } \\
\text { function }\end{array}$ & & \\
\hline $\begin{array}{l}\text { miR- } \\
424-3 p\end{array}$ & $\begin{array}{l}\text { Non-Small Cell } \\
\text { Lung Cancer }\end{array}$ & Decrease & YAP1 & $\begin{array}{l}\text { YAP1 sensitize } \\
\text { cisplatin resistant }\end{array}$ & $\begin{array}{l}\text { In } \\
\text { vivo }\end{array}$ & [27] \\
\hline & $\begin{array}{l}\text { Head and Neck } \\
\text { Squamous Cell } \\
\text { Carcinoma }\end{array}$ & Increase & - & $\begin{array}{l}\text { Increase response } \\
\text { as a biomarker }\end{array}$ & $\begin{array}{l}\text { In } \\
\text { vitro }\end{array}$ & [72] \\
\hline miR- & Endometrial & Decrease by & CDC14A & Inhibit proliferation & In & [73] \\
\hline & Adenocarcinoma & of its & $\mathrm{CDC} 25 \mathrm{~A}$ & & & \\
\hline & & & CDK6 & & & \\
\hline
\end{tabular}




\begin{tabular}{|lllllll|}
\hline $\begin{array}{l}\text { MiR- } \\
\text { 424 }\end{array}$ & Related cancer & $\begin{array}{l}\text { Expression of } \\
\text { miR }\end{array}$ & Target gene & mechanism & $\begin{array}{l}\text { Type } \\
\text { of } \\
\text { study }\end{array}$ & References \\
\hline Cervical Cancer & Decrease & KDM5B & $\begin{array}{l}\text { Blocking KDM5B } \\
\text { stop Notch pathway } \\
\text { so stop growth and } \\
\text { induce apoptosis }\end{array}$ & $\begin{array}{l}\text { In } \\
\text { vitro }\end{array}$ & [74] \\
\hline
\end{tabular}

\subsection{Role of miR-424 in drug resistance and sensitivity of breast cancer}

The most common cancer diagnosed among women around the world is breast cancer. After lung cancer, breast cancer is the second leading cause of death among women. Epigenetic events as well as miRNA expression are the master regulators of tumorigenesis and add a further layer to the complexity of breast cancer pathogenesis. Studies show that miR-424 is highly expressed in breast cancer patients compared to healthy people and can discriminate early-stage breast cancer patients from healthy controls [7, 8]. Even the presence of miR-424 in urine helps to differentiate between patients and healthy individuals $[9,10]$. Regarding the role of miR-424 in cell proliferation, it has been shown that miR-424 has an inhibitory role in cell proliferation by inhibiting CDK1 and YAP from the Hippo pathway and inhibiting p-ERK1/2 from the ERK pathway [11]. MiR-424 levels in breast cancer cells that express TRb ( thyroid receptor) are increased by the T3 hormone and targets of that like CCND2, CDK6, Cdc25, E2F3, c-Myb and CHK1 that all of them involved in proliferation are declining [12]. However, in breast cancer patients with a negative lymph node that constitutes $60 \%$ of all breast cancer cases, it has been shown that there is no association between proliferation and miR-424[13]. Hyperglycemic conditions reduce miR-424 and the inhibitory effect of miR-424 is removed from cdc 42 in this way, STAT5 is activated and causes the expression of Prdm14 gene. Increased Prdm14 expression is associated with invasion and poor prognosis [14]. MiR-424 increases metastasis by targeting Smad7 and Smurf2 because these are two negative regulators of the TGFß pathway. Binding of TGFß to its receptors is one of the signaling pathways involved in metastasis [14]. Another role of miR-424 is inhibition of CDC25A, BCL2, IGF1R genes. Increased expression of these three genes is associated with a poor prognosis [15]. Some chemotherapy drugs, such as paclitaxel (PTX), 5-fluorouracil (5-FU), doxorubicin/adriamycin (DOX), fulvestrant, taxol and cisplatin are used to treat breast cancer, but most of them may eventually lead to chemoresistance and treatment failure [6]. Mir-424 sensitizes cells to a variety of anticancer drugs by targeting Bcl2 and IGF1R and sensitize cell to cisplatin by targeting WEE1 and Chk1 $[12,15]$. Studies have shown that in Fulvestrant-resistant cell lines miR-424 level is reduced therefore, it may be possible to reduce the resistance by increasing the level of miR-424 [16]. Also, miR-424 sensitizes breast cancer cells to taxol by targeting P53, caspase 3 and Bcl2 [17].

\subsection{Role of miR-424 in drug resistance and sensitivity of gastric cancer}

Gastric Cancer is one of the most common and lethal malignancies worldwide [18]. The survival time in these patients is 5 years. Because of the high rates of postsurgical recurrence and metastasis, the prognosis of GC patients diagnosed as advanced-stage is pessimistically bad $[5,19]$ There are many signaling pathways that play a role in the onset and progression of cancers. The Hippo pathway plays an important role in cell growth and metastasis and LATS1 (Large tumor suppressor kinase 1) is one of the main members of this pathway. 
CircRNAs are a type of ncRNAs that controls gene expression [20]. CircLARP4 is a type of circRNAs that in normal cells LARP4 is high and decreases miR-424. Finally, LATS1 increases and YAP pathway decreases. But in gastric cancer, the opposite happens. CircLARP4 may function as a tumor suppressive factor in GC via regulation of miR-424/LATS1/YAP signaling pathway [5]. LncRNANNT-AS1 is a type of IncRNA (Long- noncoding RNA) that has a high expression in GC and this high expression is accompanied by a bad prognosis. LncRNAs are involved in regulating gene expression and can activate or suppress gene expression through a variety of mechanisms [19]. NNT-AS1 has been found to act as oncogene in human cancer and is a powerful cell cycle regulator through the miR-424/E2F1. LncRNANNT-AS1 inhibition inhibits the cell cycle in the G0/G1 phase and also inhibits tumor proliferation and invasion. NNT-AS1 connects to the miR-424 and NNT-AS1/miR-424 targeted E2F1 in the cycle progression regulation of GC cells. E2F1 is an important transcription factor in regulating cell cycle and apoptosis [19]. MiR-424 is involved in the drug resistance of GC patients who are being treated based on platinum chemotherapy drugs. One of the target genes of miR-424 is SMURF1, which belongs to the NEDD4 family and is involved in ubiquitinase activity. In patients who resistance to cisplatin, the reduction of miR-424 increased the SMURF1, and it also stimulated the RhoA. RhoA belongs to the Rho GTPase family and many studies have shown that it plays a role in drug resistance [21]. Another study showed that a decrease in miR-424-3p prevents an increase in ABCC2 and leads to drug resistance and tumor progression [18]. But in another study, the opposite of these results was obtained by Yon gyuan et al. who showed that both in vivo and in vitro overexpression of miR-424-3p play an important role in the resistance of gastric cancer cells to cisplatin [22].

\subsection{Role of miR-424 in drug resistance and sensitivity of osteosarcoma}

Osteosarcoma (OS) is one of the most common bone cancers in childhood and adolescence. Despite advancements in aggressive OS treatment, the prognosis has not significantly improved, and thus there is a need for alternative molecular therapies $[23,24]$. In OS, members of the miR-16 family, including miR-424, are declining and one of the most important goals of mir-424 in this malignancy is FASN (Fatty Acid Synthase) enzyme. This enzyme is involved in the catalysis of long-chain fatty acids and is expressed in many cancers. Decreased activity of this enzyme limits the growth of cancer cells and invasion and migration. FASN is one of the targets of miR-424 so maybe miR-424 stops the growth of cancer cells by inhibiting this enzyme. Other targets of this miRNA, such as CDC25A, CCNA2, CCNE1, are decreased but overexpression of miR-424 significantly decreased cyclinA2 expression $[23,24]$. In creating resistance in OS an IncRNA called LINC01116 has major role. LINC01116 inhibits the miR-424-5p expression by connecting to EZH2; thereby enhancing doxorubicin resistance osteosarcoma cells [25]. TFAP2C (Transcription factor activating protein 2 gamma) increases the expression of lincRNA (Long intergenic non-coding RNAs) LINC00922 in doxorubicin-resistant osteosarcoma. LincRNAs have emerged as tumor promoters and suppressors. LINC00922 also acts as a sponge of miR-424-5p. The formation of a reinforcing loop TFAP2C/LINC00922/miR-424-5p reduces the resistance to doxorubicin [26].

\subsection{Role of miR-424 in drug resistance and sensitivity of non- small cell lung cancer (NSCLC)}

The first common cancer in the world is lung cancer. Non-small Cell Lung Cancer (NSCLC) is a type of lung cancer whose survival time is only $15 \%$. NSCLC accounts for approximately $85 \%$ of lung cancer cases $[25,27]$. 
One of the chemotherapy treatments is based on cisplatin drugs [28]. But drug resistance has limited this method. miR-424-3p and miR-424-5p decrease in lung cancer. Both of them can control the cell growth, migration and invasion. miR-424-3p targets YAP1 (Yes-associated protein 1) protein. YAP1 was pronouncedly up-regulated in NSCLC tissues. High expression of YAP1 was significantly associated with poor overall prognosis. miR-424-3p sensitizes chemotherapy-resistant cells to paclitaxel by targeting YAP1. miR-424-5p does not have this capability. MiR-424-3p increases the level of Bax but reduces the Bcl2 level so it can increase apoptosis [27]. Acyl Protein Thioesterase 1 that also called lysophospholipase 1 (LYPLA1) is a cytosolic enzyme that is capable of catalyzing depalmitoylation targeted by miR-424. LYPLAs can interact with CD95 to stimulate depalmitoylation, thereby regulating apoptosis through CD95. So inhibition of LYPLA1 inhibits growth of cells, invasion and migration [25]. Ming Zhanga and his colleagues achieved the opposite result other target genes of miR-424 include TNFAIP1 (Tumor Necrosis Factor alpha-induced protein 1). TNFAIP1 is a tumor inhibitor in lung cancer through involvement in DNA synthesis and apoptosis. By inhibiting TNFAIP1, miR-424 increases migration and invasion and cell growth [29].

\subsection{Role of miR-424 in drug resistance and sensitivity of hepatocellular carcinoma}

Hepatocellular carcinoma (HCC) is a liver disease. $\mathrm{HCC}$ is the second leading cause of death among men and the sixth leading cause of death among women. due to high recurrence and metastasis, it has a bad prognosis. resulting in more than 695, 900 deaths happened each year. miR-424 levels are reduced in hepatocellular carcinoma [30,31]. and expression of that was inversely correlated with Ki-67. Ki-67 protein is strictly associated with cell proliferation and is frequently used as a proliferation biomarker. MiR-424 represses cell cycle/E2F signaling by direct targeting Akt3 and E2F3 to suppress HCC growth. As well as it has been proved that cyclin D and GSK3 were regulated by miR-424 and Akt3, while cyclin E, c-Myc and Cdc-2 were regulated by miR-424 and E2F3 [31]. recurrent tumors in patients following liver transplantation (LT) have been shown to reduce the expression of miR-424. Collected information demonstrates that miR-424 expression is an important indicator for predicting tumor recurrence in patients with HCC following LT [32]. MiR-424 levels in HCC cells that express $\mathrm{TRb}$ (thyroid receptor) are increased by the T3 hormone and targets of miR-424 like CCND2, CDK6, Cdc25, E2F3, c-Myb and CHK1 that all of them involved in proliferation are declining [12]. The first line of treatment of HCC patients is chemotherapy with Sorafenib. Resistance to sorafenib is one of the problems facing these patients. The protein associated with drug resistance in this patient is CBX4 (choromobox homolog 4). CBX4 is a Polycomb protein and has high expression and poor prognosis in HCC patients but miR424 reduces CBX4 expression and causes drug sensitivity [33].

\subsection{Role of miR-424 in drug resistance and sensitivity of glioma}

Glioma is one of the most important tumors of the nervous system. About $15 \%$ of patients die 1 year after diagnosis [34,35]. One of the genes involved in the molecular mechanism of glioma is PVT1 (Plasma-cytoma variability translocation 1). The expression of PVT1 is increased in glioma and the expression of miR-424 is decreased in glioma tissue. Yanjie Han et al. was found negative correlation between PVT1 and miR-424 expression in glioma cells. PVT1 inhibition increases the expression of miR-424. In short PVT1 knockdown could affect the growth of human glioma cells through the PVT1-miR-424 axis in vivo [34]. Chen Jin et al. found miR424 expression was significantly down-regulated in glioma tissues. miR-424 methylation eliminates the antitumor effects of that but, azacitidine therapy induces the expression of miR-424 and it controls cell growth by 
increasing apoptosis [35]. CCAT2, a type of IncRNA, causes glioma cells to become resistant to chemotherapy drugs it does this by destroying the normal function of miR-424 [36].

\subsection{Role of miR-424 in drug resistance and sensitivity of bladder cancer}

Bladder cancer is one of the most important health issues. Approximately $70 \%$ of patients presented with nonmuscle-invasive tumors with good prognosis, and the remaining $30 \%$ with muscle-invasive tumors have a poor five-year survival rate. MiR-424 inhibits EGFR and inhibition of EGFR inhibits proliferation and EMT through AKT and MDM2 / P53 pathway. MiR-424 is increased in bladder cancer that DNMT1(DNA methyltransferases) have inactivated. Thus, DNMT1 has a regulatory role on miR-424 [37]. Cisplatin is an important drug in the treatment of bladder cancer, but miR-424 causes resistance by targeting UNC5B and SIRT4. These are pro-apoptotic proteins [38].

\subsection{Role of miR-424 in drug resistance and sensitivity of ovarian carcinoma}

Ovarian carcinoma (OC) is one of the cancers that eventually leads to death about $70 \%$ of patients recur within 5 years. Many patients with advanced disease become refractory to conventional chemotherapeutic agents, resulting in recurrence and death. MiR-424 expression is increased in cell lines that are ALDH (+) and resistant cell lines. This indicates that miR-424 and ALDH are associated with resistance [39]. In another study, the opposite of the previous result was proven. In ovarian cancer, galectin 3 inhibits the apoptosis of cancer cells and causes drug resistance but miR-424-3p reduces its expression by targeting galectin 3 . So reduces resistance and increases sensitivity to cisplatin [40].

\subsection{Role of miR-424 in drug resistance and sensitivity of cholangiocarcinoma}

Cholangiocarcinoma (CCA) is a group of epithelial tumors arising from different locations within the biliary tree with features of cholangiocyte differentiation. It is the second most common primary hepatic malignancy, accounting for $15-20 \%$ new diagnosed cases. According to the anatomical location, cholangiocarcinoma can be classified into intrahepatic (iCCA), perihilar (pCCA), and distal (dCCA) subtypes. Among them, pCCA (50\%) and dCCA (40\%) represent the majority of cholangiocarcinoma cases, while iCCA is less than $10 \%$ of total. In iCCA, ARK5 expression is high, which causes metastasis in these patients. But miR-424-5p prevents EMT and metastasis by targeting ARK5 [41]. Chemotherapy with cisplatin and gemcitabine is the first line of treatment for CCA patients. But it has been found that an IncRNA called LIN00665 makes these cells resistant to gemcitabine. LIN00665 does this by regulating miR-424-5p / BCL9L eventually the Wnt/ß-catenin pathway is activated and the EMT is upgraded [42].

\section{Blood Malignancy}

\subsection{Role of miR-424 in drug resistance and sensitivity of acute myeloid leukemia (AML)}


Acute myeloid leukemia (AML) is a clonal and heterogeneous malignancy characterized by deregulated proliferation and inhibited differentiation of hematopoietic progenitors [43]. NPM1 (Nucleophosmin 1) mutation is seen in $60 \%$ of CN-AML (Cytogenetics normal) cases and miR-424 levels are reduced in CN-AMLs that have the NPM1 mutation. This reduction indicates the role of miR-424 in leukemogenesis [44]. Resistance to treatment is one of the most important factors in the failure of treatment of patients. TRAIL (TNF-related apoptosis-inducing ligand) belongs to the TNF family and is able to kill cancer cells. Cancer cells sometimes become resistant to TRAIL-induced apoptosis. MiR-424 levels decrease in TRAIL-resistant cells. It has been shown that an increase in miR424 level by targeting PLAG1 and inhibiting Bcl2 sensitizes cells into TRAlLinduced apoptosis [45]. THP1 cell line with MLL-MLLT3 gene fusion has monoblastic phenotype and in this cell line maturation has stopped so inducing differentiation in this cell line can be helpful. MiR424 induces differentiation towards the monocyte by targeting miR-9. MiR-9 is a differentiation suppressor [46].

\subsection{Role of miR-424 in drug resistance and sensitivity of chronic myeloid leukemia (CML)}

Chronic myeloid leukemia (CML) is a biphasic hematopoietic stem cell (HSC) myeloproliferative disorder. Its main feature is $A B L / B C R$ oncogene. The ABL-BCR gene fusion produces a protein that is an active tyrosine kinase that causes proliferation and reduction of apoptosis. Therefore, by inhibiting the activity of this tyrosine kinase, proliferation can be prevented and apoptosis can be induced. miR-424 targets $A B L$ and induces apoptosis and inhibits proliferation. And also in this way it sensitizes cells to imatinib [47]. Another factor related to drug resistance CML patients is Cobll1, which increases in blast crisis. MiR-424 destroys drug resistance by targeting this agent [48].

\section{Future Perspective}

As stated above miR-424 has been studied more in solid tumors. One of our hypotheses is the use of this microRNA in the treatment of leukemia patients. The most important mechanisms that can be used are to induce apoptosis and inhibit cancer cell proliferation. Forrest et al. Showed that increased expression of miR-424 induces cycle arrest in the G1 phase in THP1 cell line. Also, Oshrat Hershkovitz-Rokah and colleagues showed that miR-424 inhibits proliferation in the K562 cell line. MiR-424 induces these effects by acting on cell cycle regulators. Other effects of miR-424 in the treatment of leukemia include inhibition of expressed oncogenes. For example, LYPLAs increase expression in CLL and inhibit apoptosis by binding to CD95 so miR424 induces apoptosis by inhibiting LYPLAs. WEE1 is one of the genes that increase in AML and it is one of the miR-424 targets Therefore, by increasing the expression of miR-424, WEE can be inhibited and its effects can be prevented. We know that miR-424 has 4 methylated $\mathrm{CpG}$ sites and methylation reduces gene expression. Therefore, one of the ways to increase the expression of miR-424 is the use of hypomethylation drugs such as 5Azacitidine. Has been shown using of azacitidine increase the expression of miR-127 and 149 in breast cancer it also increases the expression of miR-130 in ovarian cancer. AZA is monophosphated by the uridine cytidine kinase and then diphosphate and trisphosphates by pyrimidine monophosphate kinase and pyrimidine diphosphate kinase, respectively. 3-phosphate AZA (5-aza-CTP) enters RNA. The introduction of 5-aza-CTP into RNA disrupts protein synthesis, which promotes apoptosis. A minority of this drug is converted to 5-aza-dCTP, the 3-phosphate form of decitabine, by the enzyme ribonucleotide reductase, and enters DNA during replication, binds to DNMT1, and inhibits this enzyme. Chun-Te Wu et al. Showed that expression of miR-424 increased in cancer cells that had DNMT inactivated. Therefore, the use of 5-AZA strongly increases the expression of miR- 
424 with the effect of hypomethylation and with inhibition of DNMT1. Due to the role of miR-424 in drug resistance or sensitivity in various cancers drug resistance can be eliminated by increasing or decreasing its expression.

\section{Conclusion}

microRNAs play a major role in tumorigenesis, proliferation, cell differentiation, apoptosis and metastasis. miR424 plays a major role in important processes such as cell cycle, EMT, hypoxia, tissue differentiation, tumor onset and progression, and tumor inhibition. In this study, we showed that miR-424 exhibits different functions in different cancers by targeting different genes. Due to the fact that miR-424 has $4 \mathrm{CpG}$ sites and is a hypermethylated microRNA it can be used to increase its expression and increase its function by using hypomethylating drugs such as 5-AZA or decitabine ...And by targeting genes that play an oncogenic role in leukemia, it can play an important role in inhibiting cancer.

According to the above, miR-424 can inhibit proliferation in cancer cells by targeting cell cycle regulators such as cyclin E1, cyclin D2, cyclin D, cyclin A2, CDK1, CDK6, and CDC25A. Each of these plays an important role in cell cycle. E2F1 gene is also a regulator of cell cycle, which can be one of the important goals of miR-424 in reducing cell growth. on the other hand, could play an important role in increasing cancer cell death by targeting genes involved in apoptosis these genes include Bcl2 and Akt3. In relation to the role of miR424 in the treatment of cancers, we can mention the suppression of oncogenes. WEE1 and PLAG1 are genes that are overexpressed in blood cancers miR-424 by targeting these can play a role in cancer control. One of the important recent findings is the targeting of $A B L-B C R$ in $C M L$ patients, which makes patients sensitive to imatinib. miR424 disrupts the junction between PD1-PDL1 and CTLA4-CD80 Eventually, the cells of the immune system will be able to fight the cancer cells more efficiently. MiR-424 is also involved in drug resistance, which can be eliminated by increasing or decreasing its expression according to the type of cancer. (Fig. 2 Internal and external factors that increase miR-424 expression.

\section{Abbreviations}

ABCC2, ATP binding cassette subfamily C member 2

$A B L$, Abelson proto-oncogene

AGO, Argonaut; AKT3

AKT serine/threonine kinase 3

ALDH, Aldehyde dehydrogenase

AML, Acute myeloid leukemia

APTX, Aprataxin; Bcl2, B-cell lymphoma 2

Bcl9l, B-cell CLL/lymphoma 9-like protein

$\mathrm{BCR}$, Breakpoint cluster region

Page 13/22 
CCAT2, Colon cancer associated transcript 2

CCNA2, Cyclin A2

CCNE1, Cyclin E1

CCND2, cyclin D2

CDC25A, Cell division cycle

CDK, Cycle-dependent kinase

CHK, Checkpoint kinase

$\mathrm{CML}$, Chronic myeloid leukemia

COP1, Constitutive photomorphogenic-1

CTAL4, cytotoxic T lymphocyte associated protein 4

CUL2, Cullin 2

DCLK1, Doublecortin like kinase 1

DGRC8, Digeorge syndrome critical region gene 8

EGFR, Epidermal growth factor receptor

EMT, Epithelial-mesenchymal transition

ERK, Extracellular signal-regulated kinases

EZH2, Enhancer of zeste 2 Polycomb repressive complex 2 subunits

FGF, Fibroblast growth factors

GSK3, Glycogen synthase kinase-3

IGF1R, Insulin-like growth factor 1 receptor

KDM5B, Lysine demethylase 5B

MALAT1, Metastasis associated lung adenocarcinoma transcript 1

MEK1, MAP (mitogen-activated protein) kinase/ERK (extracellular signal-regulated kinase) kinase 1

MMSET, multiple myeloma SET domain

MYB, Myeloblastosis

NEDD4, Neuronal precursor cell-expressed developmentally downregulated 4 
PD1, Programmed cell death protein 1

PDGF-R, Platelet-derived growth factor receptors

PLAG1, Pleomorphic adenoma gene

Pre-miRNA, Precursor miRNA

Pri-miRNA, Primary RNA

PRKCD, Protein kinase $\mathrm{C}$ delta

PSAT1, Phosphoserine aminotransferase 1

RBBP6, Retinoblastoma binding protein 6

RISC, RNA-induced silencing complex

SIAH1, Siah E3 ubiquitin protein ligase 1

SIRT4, Sirtuin 4

Smad, Small worm phenotype, mothers against decapentaplegic

Smurf, Smad ubiquitination regulatory factor

STAT5, Signal transducer and activator of transcription 5

TGF-B, Transforming growth factor beta

TRBP, TAR RNA binding protein

TWIST1, Twist family BHLH transcription factor 1

UNC5B, Unc-5 netrin receptor B

VEGFR2, Vascular endothelial growth factor receptor 2

WEE, Western equine encephalitis

Wnt, Wingless and int-1

YAP, Yes-associated protein

\section{Declarations}

Ethics approval and consent to participate: This study was approved by the Ethics Committee of Tabriz University of Medical Sciences, Tabriz, Iran

Consent for publication: Not Applicable 
Availability of data and materials: The data that support the findings of this study are available on request from the corresponding author. The data are not publicly available due to privacy or ethical restrictions.

Competing Interests: The authors declare no conflict of interest.

Funding: This study was supported by Immunology Research Center of Tabriz University of Medical Sciences, Tabriz, Iran

Author's contribution: Mohammad Reza Alivand and Saeed Solali designed the study. Fatemeh Najafi wrote the first draft of the manuscript. Shohreh Karimi, Bahareh Kazemi, Mahdi Derakhshani, and Sajjad Vakili gathered the data. Saeed Solali and Mohammad Reza Alivand supervised the study. Zahra Foruzandeh and Farhad Seif revised the manuscript for important intellectual content. All authors read and approved the final manuscript.

Acknowledgements: We would like to express our gratitude to personnel of Immunology and Hematology Research Center.

\section{References}

1. Wang H, Peng R, Wang J, Qin Z et al (2018) Circulating microRNAs as potential cancer biomarkers: the advantage and disadvantage. Clinical epigenetics 10(1):1-10

2. Vasan N, Baselga J, Hyman DM (2019) A view on drug resistance in cancer. Nature 575(7782):299-309

3. Wang F, Liang R, Tandon N, Matthews ER et al (2019) H19X-encoded miR-424 (322)/-503 cluster: emerging roles in cell differentiation, proliferation, plasticity and metabolism. Cell Mol Life Sci 76(5):903-920

4. Soheilifar MH, Vaseghi H, Seif F, Ariana M et al (2021) Concomitant overexpression of mir-182-5p and mir182-3p raises the possibility of IL-17-producing Treg formation in breast cancer by targeting CD3d, ITK, FOX01, and NFATs: A meta-analysis and experimental study. Cancer Sci 112(2):589

5. Zhang J, Liu H, Hou L, Wang G et al (2017) Circular RNA_LARP4 inhibits cell proliferation and invasion of gastric cancer by sponging miR-424-5p and regulating LATS1 expression. Mol Cancer 16(1):1-16

6. Si W, Shen J, Zheng H, Fan W (2019) The role and mechanisms of action of microRNAs in cancer drug resistance. Clinical epigenetics 11(1):1-24

7. Zhang L, Xu Y, Jin X, Wang Z et al (2015) A circulating miRNA signature as a diagnostic biomarker for noninvasive early detection of breast cancer. Breast Cancer Res Treat 154(2):423-434

8. Zare M, Bastami M, Solali S, Alivand MR (2018) Aberrant miRNA promoter methylation and EMT-involving miRNAs in breast cancer metastasis: diagnosis and therapeutic implications. J Cell Physiol 233(5):37293744

9. Hirschfeld M, Rücker G, Weiß D, Berner K et al (2020) Urinary exosomal microRNAs as potential non-invasive biomarkers in breast cancer detection. Mol Diagn Ther 24(2):215-232

10. Shivapurkar N, Vietsch EE, Carney E, Isaacs C et al (2017) Circulating microRNAs in patients with hormone receptor-positive, metastatic breast cancer treated with dovitinib. Clinical and translational medicine 6(1):110

11. Xie D, Song H, Wu T, Li D et al (2018) MicroRNA-424 serves an anti-oncogenic role by targeting cyclindependent kinase 1 in breast cancer cells. Oncol Rep 40(6):3416-3426 
12. Ruiz-Llorente L, Ardila-González S, Fanjul LF, Martínez-Iglesias 0 et al (2014) microRNAs 424 and 503 are mediators of the anti-proliferative and anti-invasive action of the thyroid hormone receptor beta. Oncotarget 5(10):2918

13. Jonsdottir K, Janssen SR, Da Rosa FC, Gudlaugsson E et al (2012) Validation of expression patterns for nine miRNAs in 204 lymph-node negative breast cancers. PLoS ONE 7(11):e48692

14. Nandy SB, Orozco A, Lopez-Valdez R, Roberts R et al (2017) Glucose insult elicits hyperactivation of cancer stem cells through miR-424-cdc42-prdm14 signalling axis. Br J Cancer 117(11):1665-1675

15. Otsuka K, Yamamoto Y, Ochiya T (2018) Regulatory role of resveratrol, a microRNA-controlling compound, in HNRNPA1 expression, which is associated with poor prognosis in breast cancer. Oncotarget 9(37):24718

16. Rodriguez-Barrueco R, Nekritz EA, Bertucci F, Yu J et al (2017) miR-424 (322)/503 is a breast cancer tumor suppressor whose loss promotes resistance to chemotherapy. Genes Dev 31(6):553-566

17. Dastmalchi N, Safaralizadeh R, Hosseinpourfeizi MA, Baradaran B et al (2021) MicroRNA-424-5p enhances chemosensitivity of breast cancer cells to Taxol and regulates cell cycle, apoptosis, and proliferation. Mol Biol Rep 48(2):1345-1357

18. Li Y, Liu H, Cui Y, Chen H et al (2020) miR-424-3p contributes to the malignant progression and chemoresistance of gastric cancer. OncoTargets and therapy 13:12201

19. Chen B, Zhao Q, Guan L, Lv H et al (2018) Long non-coding RNA NNT-AS 1 sponges miR-424/E2F1 to promote the tumorigenesis and cell cycle progression of gastric cancer. J Cell Mol Med 22(10):4751-4759

20. Foruzandeh Z, Zeinali-Sehrig F, Nejati K, Rahmanpour D et al (2021) CircRNAs as potent biomarkers in ovarian cancer: a systematic scoping review. Cell Mol Biol Lett 26(1):1-29

21. Lu L, Wu M, Lu Y, Zhao Z et al (2019) MicroRNA-424 regulates cisplatin resistance of gastric cancer by targeting SMURF1 based on GEO database and primary validation in human gastric cancer tissues. OncoTargets and therapy 12:7623

22. Wen J, Hu Y, Liu Q, Ling Y et al (2018) miR-424 coordinates multilayered regulation of cell cycle progression to promote esophageal squamous cell carcinoma cell proliferation. EBioMedicine 37:110-124

23. Long XH, Mao JH, Peng AF, Zhou Y et al (2013) Tumor suppressive microRNA-424 inhibits osteosarcoma cell migration and invasion via targeting fatty acid synthase. Experimental and therapeutic medicine 5(4):1048-1052

24. Shekhar R, Priyanka P, Kumar P, Ghosh T et al (2019) The microRNAs miR-449a and miR-424 suppress osteosarcoma by targeting cyclin A2 expression. J Biol Chem 294(12):4381-4400

25. Mohammed A, Zhang C, Zhang S, Shen Q et al (2019) Inhibition of cell proliferation and migration in nonsmall cell lung cancer cells through the suppression of LYPLA1. Oncol Rep 41(2):973-980

26. Gu Z, Zhou Y, Cao C, Wang X et al (2020) TFAP2C-mediated LINC00922 signaling underpins doxorubicinresistant osteosarcoma. Biomed Pharmacother 129:110363

27. Zhang M, Zeng J, Zhao Z, Liu Z (2017) Loss of MiR-424-3p, not miR-424-5p, confers chemoresistance through targeting YAP1 in non-small cell lung cancer. Mol Carcinog 56(3):821-832

28. Safi A, Bastami M, Delghir S, Ilkhani K et al (2021) miRNAs modulate the dichotomy of cisplatin resistance or sensitivity in breast cancer: an update of therapeutic implications. Anti-Cancer Agents in Medicinal Chemistry (Formerly Current Medicinal Chemistry-Anti-Cancer Agents). 21:1069-10819 
29. Zhang M, Gao C, Yang Y, Li G et al (2017) MiR-424 promotes non-small cell lung cancer progression and metastasis through regulating the tumor suppressor gene TNFAIP1. Cell Physiol Biochem 42(1):211-221

30. Yao H, Liu X, Chen S, Xia W et al (2015) Decreased expression of serum miR-424 correlates with poor prognosis of patients with hepatocellular carcinoma. Int J Clin Exp Pathol 8(11):14830

31. Yang H, Zheng W, Shuai X, Chang R-M et al (2015) MicroRNA-424 inhibits Akt3/E2F3 axis and tumor growth in hepatocellular carcinoma. Oncotarget 6(29):27736

32. Wu L, Yang F, Lin B, Chen X et al (2018) MicroRNA-424 expression predicts tumor recurrence in patients with hepatocellular carcinoma following liver transplantation. Oncology letters 15(6):9126-9132

33. Ma B, Tian Z, Han H, Dong B et al (2019) MiR424 and the CBX4 inhibitor UNC3866 Efficiently Suppress YAP Nucleus Translocation in Hepatocellular Carcinoma Cells to Protect Against Sorafenib Resistance. Available at SSRN 3454674.

34. Han Y, Li X, He F, Yan J et al (2019) Knockdown of LncRNA PVT1 inhibits glioma progression by regulating miR-424 expression. Oncol Res 27(6):681

35. Jin C, Li M, Ouyang Y, Tan Z et al (2017) MiR-424 functions as a tumor suppressor in glioma cells and is down-regulated by DNA methylation. J Neurooncol 133(2):247-255

36. Ding J, Zhang L, Chen S, Cao H et al (2020) IncRNA CCAT2 enhanced resistance of glioma cells against chemodrugs by disturbing the normal function of miR-424. OncoTargets and therapy 13:1431

37. Wu C-T, Lin W-Y, Chang Y-H, Lin P-Y et al (2015) DNMT1-dependent suppression of microRNA424 regulates tumor progression in human bladder cancer. Oncotarget 6(27):24119

38. Yu M, Ozaki T, Sun D, Xing H et al (2020) HIF-1a-dependent miR-424 induction confers cisplatin resistance on bladder cancer cells through down-regulation of pro-apoptotic UNC5B and SIRT4. Journal of Experimental \& Clinical Cancer Research 39(1):1-13

39. Park YT, Jeong J-y, Lee M-j, Kim K-i et al (2013) MicroRNAs overexpressed in ovarian ALDH1-positive cells are associated with chemoresistance. Journal of ovarian research 6(1):1-11

40. Bieg D, Sypniewski D, Nowak E, Bednarek I (2019) MiR-424-3p suppresses galectin-3 expression and sensitizes ovarian cancer cells to cisplatin. Arch Gynecol Obstet 299(4):1077-1087

41. Wu J, Yang B, Zhang Y, Feng $X$ et al (2019) miR-424-5p represses the metastasis and invasion of intrahepatic cholangiocarcinoma by targeting ARK5. Int J Biol Sci 15(8):1591

42. Lu M, Qin X, Zhou Y, Li G et al (2021) Long non-coding RNA LINC00665 promotes gemcitabine resistance of Cholangiocarcinoma cells via regulating EMT and stemness properties through miR-424-5p/BCL9L axis. Cell Death Dis 12(1):1-17

43. Yuan X-Q, Chen P, Du Y-X, Zhu K-W et al (2019) Influence of DNMT3A R882 mutations on AML prognosis determined by the allele ratio in Chinese patients. Journal of translational medicine 17(1):1-10

44. Faraoni I, Laterza S, Ardiri D, Ciardi C et al (2012) MiR-424 and miR-155 deregulated expression in cytogenetically normal acute myeloid leukaemia: correlation with NPM1 and FLT3 mutation status. J Hematol Oncol 5(1):1-5

45. Sun Y-p, Lu F, Han X-y, Ji M et al (2016) MiR-424 and miR-27a increase TRAIL sensitivity of acute myeloid leukemia by targeting PLAG1. Oncotarget 7(18):25276

46. Forrest AR, Kanamori-Katayama M, Tomaru Y, Lassmann T et al (2010) Induction of microRNAs, mir-155, mir-222, mir-424 and mir-503, promotes monocytic differentiation through combinatorial regulation. 
Leukemia 24(2):460-466

47. Hershkovitz-Rokah O, Modai S, Pasmanik-Chor M, Toren A et al (2015) Restoration of miR-424 suppresses BCR-ABL activity and sensitizes CML cells to imatinib treatment. Cancer Lett 360(2):245-256

48. Han SH, Kim S-H, Hyoung-June K, Yoonsung L et al (2017) Mir-424 and Mir-503 Regulates Cobll1 Expression during the CML Progression. American Society of Hematology Washington, DC;

49. Li Q, Qiu X-M, Li Q-H, Wang X-Y et al (2015) MicroRNA-424 may function as a tumor suppressor in endometrial carcinoma cells by targeting E2F7. Oncol Rep 33(5):2354-2360

50. Dong P, Xiong Y, Yue J, Hanley SJ et al (2018) miR-34a, miR-424 and miR-513 inhibit MMSET expression to repress endometrial cancer cell invasion and sphere formation. Oncotarget 9(33):23253

51. D'Arcangelo D, Facchiano F, Nassa G, Stancato A et al (2016) PDGFR-alpha inhibits melanoma growth via CXCL10/IP-10: a multi-omics approach. Oncotarget 7(47):77257

52. Cheung KS, Chan EW, Wong AY, Chen L et al (2018) Long-term proton pump inhibitors and risk of gastric cancer development after treatment for Helicobacter pylori: a population-based study. Gut 67(1):28-35

53. Fang Y, Liang X, Xu J, Cai X (2018) miR-424 targets AKT3 and PSAT1 and has a tumor-suppressive role in human colorectal cancer. Cancer management and research 10:6537

54. Hua F, Li C-H, Chen X-G, Liu X-P (2018) Long noncoding RNA CCAT2 knockdown suppresses tumorous progression by sponging miR-424 in epithelial ovarian cancer. Oncol Res 26(2):241

55. Wu X, Ruan Y, Jiang H, Xu C (2017) MicroRNA-424 inhibits cell migration, invasion, and epithelial mesenchymal transition by downregulating doublecortin-like kinase 1 in ovarian clear cell carcinoma. Int $\mathrm{J}$ Biochem Cell Biol 85:66-74

56. Wu K, Hu G, He X, Zhou P et al (2013) MicroRNA-424-5p suppresses the expression of SOCS6 in pancreatic cancer. Pathology \& Oncology Research 19(4):739-748

57. Cong D, He M, Chen S, Liu X et al (2015) Expression profiles of pivotal microRNAs and targets in thyroid papillary carcinoma: an analysis of The Cancer Genome Atlas. OncoTargets and therapy 8:2271

58. Dallavalle C (2016) A novel oncogenic axis involving the ETS factor ESE3/EHF, miR-424, COP1 and STAT3 drives prostate tumor progression. University of Geneva

59. Richardsen E, Andersen S, Al-Saad S, Rakaee M et al (2019) Low expression of miR-424-3p is highly correlated with clinical failure in prostate cancer. Sci Rep 9(1):1-10

60. Li D, Liu K, Li Z, Wang J et al (2018) miR-19a and miR-424 target TGFBR3 to promote epithelial-tomesenchymal transition and migration of tongue squamous cell carcinoma cells. Cell Adhes Migr 12(3):236-246

61. Chen B, Duan L, Yin G, Tan J et al (2013) Simultaneously expressed miR-424 and miR-381 synergistically suppress the proliferation and survival of renal cancer cells--Cdc2 activity is up-regulated by targeting WEE1. Clinics 68:825-833

62. Xu J, Fang Y, Wang X, Wang F et al (2016) CUL2 overexpression driven by CUL2/E2F1/miR-424 regulatory loop promotes HPV16 E7 induced cervical carcinogenesis. Oncotarget 7(21):31520

63. Gao Y-L, Zhao Z-S, Zhang M-Y, Han L-J et al (2017) Long noncoding RNA PVT1 facilitates cervical cancer progression via negative regulating of miR-424. Oncol Res 25(8):1391

64. Varghese VK, Shukla V, Kabekkodu SP, Pandey D et al (2018) DNA methylation regulated microRNAs in human cervical cancer. Mol Carcinog 57(3):370-382 
65. Wang X, Li Q, Jin H, Zou H et al (2016) miR-424 acts as a tumor radiosensitizer by targeting aprataxin in cervical cancer. Oncotarget 7(47):77508

66. Fei Z, Qiu M, Qi X, Dai Y et al (2018) MicroRNA-424 suppresses the proliferation of hemangioma-derived endothelial cells by targeting VEGFR-2. Mol Med Rep 18(4):4065-4071

67. Nakashima T, Jinnin M, Etoh T, Fukushima S et al (2010) Down-regulation of mir-424 contributes to the abnormal angiogenesis via MEK1 and cyclin E1 in senile hemangioma: its implications to therapy. PLoS ONE 5(12):e14334

68. Li M-M, Dong C-X, Sun B, Lei H-Z et al (2019) LncRNA-MALAT1 promotes tumorogenesis of infantile hemangioma by competitively binding miR-424 to stimulate MEKK3/NF-KB pathway. Life Sci 239:116946

69. Yang L, Dai J, Li F, Cheng $\mathrm{H}$ et al (2017) The expression and function of miR-424 in infantile skin hemangioma and its mechanism. Sci Rep 7(1):1-14

70. Pallasch CP, Patz M, Park YJ, Hagist S et al (2009) miRNA deregulation by epigenetic silencing disrupts suppression of the oncogene PLAG1 in chronic lymphocytic leukemia. Blood, The Journal of the American Society of Hematology 114(15):3255-3264

71. Imig J, Motsch N, Zhu JY, Barth S et al (2011) microRNA profiling in Epstein-Barr virus-associated B-cell lymphoma. Nucleic Acids Res 39(5):1880-1893

72. Chen L, Wen Y, Zhang J, Sun W et al (2018) Prediction of radiotherapy response with a 5-microRNA signature-based nomogram in head and neck squamous cell carcinoma. Cancer Med 7(3):726-735

73. Devor EJ, Cha E, Warrier A, Miller MD et al (2018) The miR-503 cluster is coordinately under-expressed in endometrial endometrioid adenocarcinoma and targets many oncogenes, cell cycle genes, DNA repair genes and chemotherapy response genes. OncoTargets and therapy 11:7205

74. Zhou Y, An Q, Guo R-x, Qiao Y-h et al (2017) miR424-5p functions as an anti-oncogene in cervical cancer cell growth by targeting KDM5B via the Notch signaling pathway. Life Sci 171:9-15

\section{Figures}




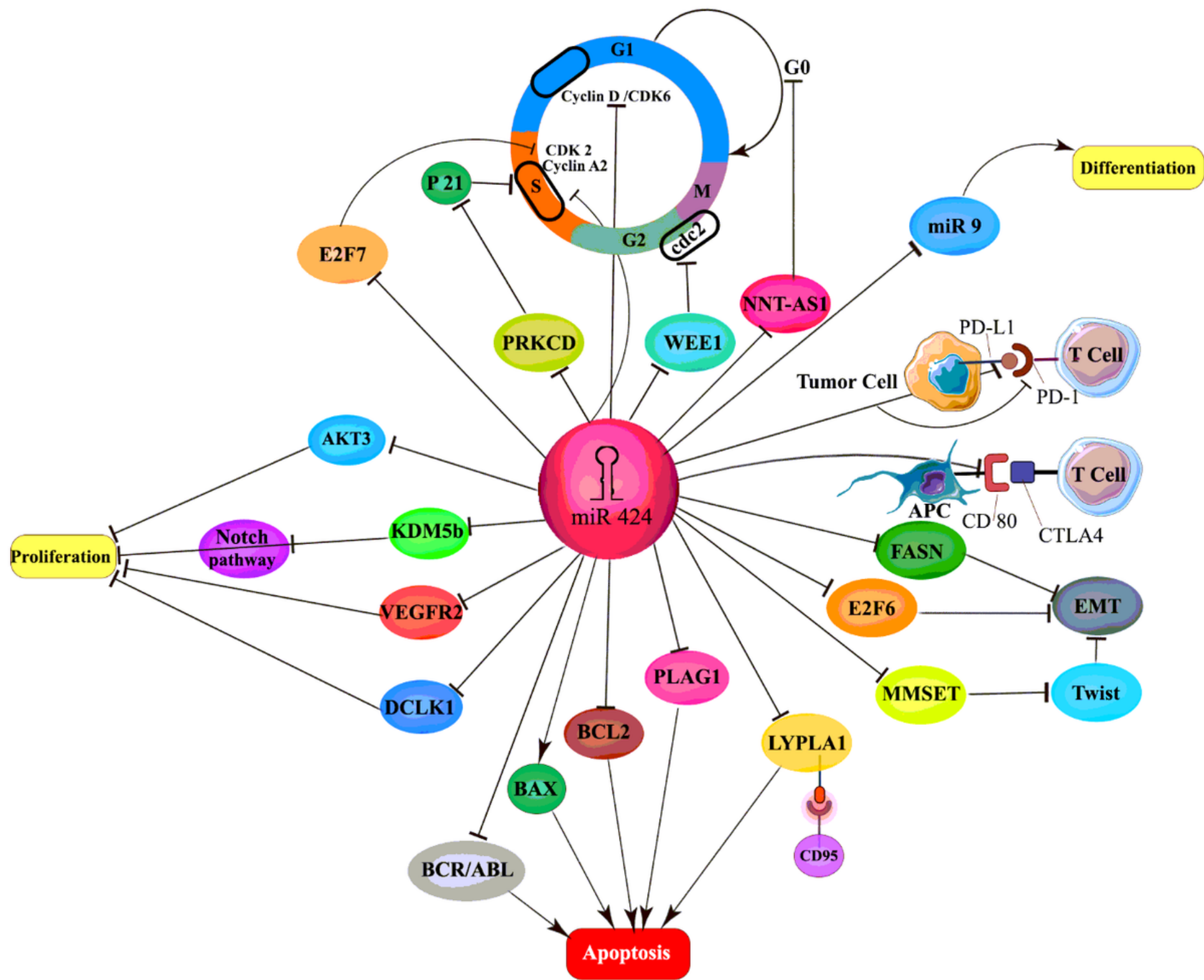

\section{Figure 1}

The role of miR-424 through inhibition or induction of various genes in inhibition of proliferation, cell cycle, EMT and induction of apoptosis and differentiation 


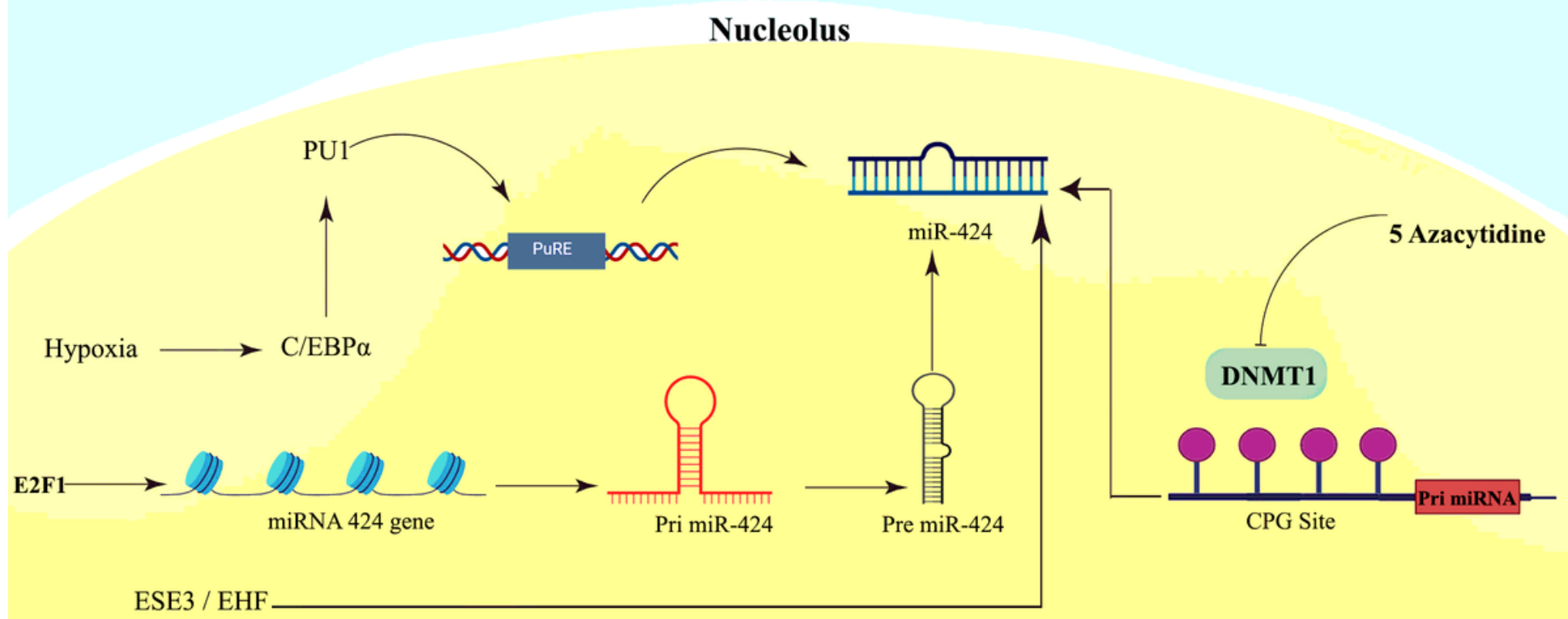

Figure 2

Internal and external factors that increase miR-424 expression. 